\title{
Effect of Biochar from Urban Waste and Eco-enzymes on Growth and Yield of Shallots (Allium ascalonicum, $\mathrm{L}$ )
}

\author{
Elisabet Restiana Jaya*, Yohanes Parlindungan Situmeang, and \\ Anak Agung Sagung Putri Risa Andriani \\ Agrotechnology Study Program, Faculty of Agriculture, Warmadewa University, Denpasar, Bali, Indonesia \\ * E-mail: restiana01.jaya98@gmail.com
}

\begin{abstract}
This study aims to determine the effect of biochar dose from urban waste and the concentration of eco-enzymes and their interactions on the growth and yield of shallots. The research was carried out in the greenhouse of the Faculty of Agriculture, Warmadewa University with an altitude of $25 \mathrm{~m}$ above sea level, and took place from April to June 2021. This study used a factorial randomized block design method consisting of two factors. The first factor is the dose of biochar with 4 levels $\left(0 ; 5 ; 10\right.$; and 15 tons ha $\left.{ }^{-1}\right)$, while the second factor is the concentration of eco-enzyme which consists of 4 treatment levels $\left(0 ; 7.5 ; 15.0\right.$; and $\left.22.5 \mathrm{ml} \mathrm{l}^{-1}\right)$. The results showed that the interaction between the dose of biochar and the concentration of eco-enzyme had a significant effect on the fresh weight of the stover per clump and had a very significant effect on the dry weight of the stover per clump, but had no significant effect on other variables. The treatment dose of biochar and ecoenzyme had a very significant effect on all observed variables. The results showed that the biochar and ecoenzyme treatments had a very significant effect on all observed variables. The application of biochar and ecoenzyme has a very significant effect on all observed variables. The provision of biochar treatment from urban waste was able to increase the fresh weight of tubers in the 15-ton ha-1 treatment, which was an increase of $39.40 \%$ compared to without biochar, while the highest fresh fruit weight was obtained in the eco-enzyme treatment of $22.5 \mathrm{ml} \mathrm{l}^{-1}$, which increased by $29.77 \%$ compared without eco-enzyme.
\end{abstract}

Keywords: Biochar; urban waste; eco-enzyme; shallots.

\section{Introduction}

Shallots (Allium ascalonicum L.) is one of the leading commodities in several regions in Indonesia which is used as a cooking spice and contains several substances that are beneficial to health, its properties are anti-cancer and substitute for antibiotics, lowering blood pressure, cholesterol [1]. Shallots are also one of the national priority and superior vegetable commodities that can be developed through increasing planting area, productivity, production stability, and quality [2].

The need for shallots per year in Bali is very large, reaching 11.268 tons, this is in line with the increasing number of people who increase every year, while the production of shallots decreases. Shallot production in Bali in 5 years (2015-2019) has experienced ups and downs every year, in 2015 the production of shallots reached 10,147 tons while in the following year 2016 it increased to 18,024 tons, in 2017 and 2018 there was a drastic increase of 20,287 tons and 24,267 tons while in 2019 it decreased to 19,687 tons. Meanwhile, onion production in Bali is found in Songan Village, Kintamani, Bangli Regency, and thereare scattered in several districts such as in Karangasem, Buleleng, Klungkung, and a little in Jembrana [3]. One of the efforts to get very good growth and yield of shallot plants is to provide fertilization, because fertilization is an action that can add nutrients to the soil, either directly or indirectly so that it can provide sufficient nutrients for plants. The availability of nutrients in the soil can affect plant growth and development. Organic fertilizer comes from plants and or animals that have undergone an engineering process and contain nutrients 
needed by plants [4]. Organic fertilizers are useful for restoring the physical properties of the soil. The use of fertilizers can improve the physical, biological, and chemical properties of the soil to increase the growth and yield of shallots.

The provision of fertilizer into the soil can be useful for restoring soil physical properties, soil biology, and soil chemistry so that it can increase plant growth and yield. Shallot plants cannot tolerate dry land because their roots are short so they will wilt, in the process of growth and development of shallot plants require sufficient water and also waterlogged because it can cause disease caused by fungi [5].

Biochar is a solid material formed from a combination of biomass. Biochar can improve soil function and reduce emissions from biomass that naturally decomposes into greenhouse gases. The manufacture of biochar has been known since 2000 years ago in the Amazon (Terra Preta). These activitiescan increase carbon and turn agricultural waste into soil improvement and can improve food security. This process can produce good fiber and very which is needed by the soil to hold nutrients and water [6]. Inagricultural cultivation, the use of biochar in nutrient-poor soils and lack of water because biochar is used as a soil enhancer to improve soil fertility, soil quality, and crop productivity, thereby increasing crop yields [7]. Giving biochar into the soil can increase nitrogen (N) fixation in the soil, leaching of $\mathrm{N}$ can be significantly reduced [8] so that nitrogen $(\mathrm{N})$ can be well available to plants so that it does not experience a shortage, biochar can also hold phosphor $(\mathrm{P})$ that cannot be retained by organic matter. Biochar canincrease soil fertility, absorb toxic nutrients, and mitigate climate change [9]. The advantage of biochar onplant productivity is that it does not provide high amounts of nutrients, giving positive plant responses [10].

Giving coconut shell biochar as much as 15 tons gave a very good response to corn yields in three growing seasons [11]. Research [12], showed that the application of 10 tons of bamboo waste biochar affected plant height, total wet weight of planting, and total oven-dry weight of corn plants. The results of further research showed that the best corn plant growth was obtained with a dose of 10 tons ha ${ }^{-1}$ biochar treatment [13]. Results research [14], giving 5 tons/ha ofbiochar more effective to increase total pore space, fast drainage pore, and water pore, and reduce slow drainage pore compared to other treatments so that able to increase soybean yields. The application of biochar from animal dung at a dose of 10 tons per ha [15] and 15 tons per ha $[16,17,18]$ can significantly increase the yield of red chili.

The creation of eco-enzymes is a small step and the first step in efforts to participate in climate change mitigation. The utilization of household waste into eco-enzymes will reduce landfill waste in landfills because piles of waste will produce methane gas which contributes to global warming [19]. Eco-enzyme is produced for three months using organic waste such as fruit peels and others. Each treatment added $10 \%$ frangipani sandalwood extract. Controlled variables include the length of time of fermentation, the composition of water, brown sugar, yeast (Saccharomyces cerevisiae) with a fixed amount. The experimental results show that the longer the fermentation time, the higher the alcohol concentration results, while the $\mathrm{pH}$ value will decrease [20]. The utilization of organic waste to make eco- enzymes is very suitable to reduce the amount of household waste [21]. Eco-enzymes can also be used to stimulate plant hormones to improve fruit and vegetable quality and to increase crop yields [22].

Eco-enzyme is useful for fertilizing soil and plants, as well as improving the quality and taste of fruit with a dose of $15 \mathrm{ml} \mathrm{l}^{-1}$. Eco-enzyme is also very effective to repel plant pests such as orchids and vegetables and even pests or disturbing animals around plants, such as cockroaches, ants, flies, mosquitoes, and other insects by using a dose of $15 \mathrm{ml} \mathrm{l}^{-1}$ [23]. The purpose of the research The purpose of this study was to determine the effect of biochar from urban waste and the concentration of eco-enzymes and their interactions on the growth and yield of shallots. 


\section{Material and Methods}

The research was conducted at Warmadewa University, Faculty of Agriculture, precisely in a greenhouse and it has a height of $25 \mathrm{~m}$ above sea level. The research was carried out from April to June 2021. The materials used during this research were: onion seeds of the local variety Bima, biochar, eco-enzymes, and pesticides. The biochar used comes from power plant residues made from organic waste pellets from the Klungkung final disposal site, while eco-enzymes are made from organic waste: fruit peels, vegetables, or other organic waste that is fermented in a container filled with water and sugar/ molasses stored or fermented for nine months. While the tools used are hoes, scales, plastic polybags, paper labels, hoses or sprayers, rulers, ovens, measuring cups, aqua, pencils, and other documentation tools.

In this study using a factorial Randomized Block Design (RAK) method consisting of two factors, namely: The first factor is the dose of biochar (B) consisting of 4 levels of treatment, namely; $\mathrm{B} 0=0$ tons ha ${ }^{-1}, \mathrm{~B} 1=5$ tons ha ${ }^{-1}(12.5 \mathrm{~g} /$ polybag $), \mathrm{B} 2=10$ tons ha ${ }^{-1}(25 \mathrm{~g} /$ polybag $)$, and B3 $=15$ tons $\mathrm{ha}^{-1}$ (37.5 g/polybag), The second factor is the concentration of eco-enzyme (E) consisting of 4 levels of treatment, namely; $\mathrm{E} 0=0, \mathrm{E} 1=7.5 \mathrm{ml} \mathrm{l}^{-1}, \mathrm{E} 1=15 \mathrm{ml} \mathrm{l}^{-1}$, and E3 $=22.5 \mathrm{ml} \mathrm{l}^{-1} .16$ treatment combinations were repeated 3 times so that 48 experimental units were obtained. The variables observed in this study were the number of leaves, plant height, fresh weight of tubers per clump, number of tubers per clump, fresh weight of stover per clump, the oven-dry weight of tubers per clump, oven-dry weight of stover per clump, and harvest index. The research data were analyzed using statistical variance according to the research design. For treatments that have a significant effect, the LSD test is also carried out at the 5\% level, correlation analysis is also carried out to determine the relationship between the observed variables.

\section{Results and Discussion}

The significant effect of biochar and eco-enzyme and their interaction $(\mathrm{BxE})$ on the variables studied are presented in Table 1.

Table 1

Table of significant effects due to treatment with biochar and eco-enzyme and their interactions on growth and yield variables of shallots

\begin{tabular}{|c|c|c|c|c|}
\hline$\overline{\mathrm{No}}$ & Variable & $\begin{array}{c}\text { Biochar } \\
\text { (B) }\end{array}$ & $\begin{array}{c}\text { Eco-enzyme } \\
(\mathrm{E})\end{array}$ & $\begin{array}{c}\text { Interaksi } \\
\mathrm{B} \times \mathrm{E}\end{array}$ \\
\hline 1. & Maximum plant height $(\mathrm{cm})$ & $* *$ & $* *$ & ns \\
\hline 3. & Number of tubers per clump (tubers) & $* *$ & $* *$ & ns \\
\hline 4. & Fresh tuber weight per clump (g) & $* *$ & $* *$ & ns \\
\hline 5. & Fresh weight of stover per clump (g) & $* *$ & $* *$ & $*$ \\
\hline 7. & The dry weight of stover per clump (g) & $* *$ & $* *$ & $* *$ \\
\hline 8. & Harvest index $(\%)$ & $* *$ & $* *$ & ns \\
\hline
\end{tabular}

Information: $*$ Significantly $(\mathrm{P}<0.05),{ }^{*}=$ Very Significantly $(\mathrm{P}<0.01) \mathrm{ns}=$ no significant $(\mathrm{P} \geq 0.05)$

From Table 1, it can be seen that there was an interaction between the dose of biochar treatment and the concentration of eco-enzyme $(\mathrm{BxE})$ which had a significant effect $(\mathrm{P}<0.05)$ on the fresh weight of the stover per clump and had a very significant effect $(\mathrm{P}<0.01)$ on the dry weight of the stover and had no significant effect with other treatment interactions. The dose of biochar and ecoenzyme treatment had a very significant effect $(\mathrm{P}<0.01)$ on all variables studied. 
Table 2

The average of all variables observed in the treatment of biochar from urban waste (B) and the concentration of eco-enzymes (E)

\begin{tabular}{|c|c|c|c|c|c|c|c|c|}
\hline Treatment & $\begin{array}{c}\text { Maximum } \\
\text { plant } \\
\text { height }\end{array}$ & $\begin{array}{c}\text { Number } \\
\text { of } \\
\text { leaves }\end{array}$ & $\begin{array}{c}\text { Number of } \\
\text { tubers per } \\
\text { clump }\end{array}$ & $\begin{array}{c}\text { Fresh weight } \\
\text { tubers per } \\
\text { clump }\end{array}$ & $\begin{array}{c}\text { Fresh weight } \\
\text { of stover } \\
\text { per clump }\end{array}$ & $\begin{array}{c}\text { Oven dry } \\
\text { weight of } \\
\text { tubers per } \\
\text { clump }\end{array}$ & $\begin{array}{c}\text { The dry } \\
\text { weight of } \\
\text { stover per } \\
\text { clump }\end{array}$ & $\begin{array}{c}\text { Harvest } \\
\text { index }\end{array}$ \\
\cline { 2 - 10 } & $(\mathrm{cm})$ & $($ sheet $)$ & $(\mathrm{g})$ & $(\mathrm{g})$ & $(\mathrm{g})$ & $(\mathrm{g})$ & $(\mathrm{g})$ & $(\%)$ \\
\hline B0 & $9.14 \mathrm{~b}$ & $11.17 \mathrm{c}$ & $3.17 \mathrm{~b}$ & $8.73 \mathrm{c}$ & $15.23 \mathrm{c}$ & $2.74 \mathrm{~b}$ & $2.73 \mathrm{~d}$ & $36.58 \mathrm{a}$ \\
\hline B1 & $9.78 \mathrm{~b}$ & $14.42 \mathrm{~b}$ & $3.75 \mathrm{ab}$ & $10.03 \mathrm{~b}$ & $23.08 \mathrm{~b}$ & $3.30 \mathrm{a}$ & $3.18 \mathrm{c}$ & $31.55 \mathrm{~b}$ \\
\hline B2 & $10.33 \mathrm{ab}$ & $16.58 \mathrm{a}$ & $4.25 \mathrm{a}$ & $11.57 \mathrm{a}$ & $23.31 \mathrm{~b}$ & $3.42 \mathrm{a}$ & $4.75 \mathrm{~b}$ & $35.66 \mathrm{a}$ \\
\hline B3 & $10.49 \mathrm{a}$ & $16.67 \mathrm{a}$ & $4.42 \mathrm{a}$ & $12.17 \mathrm{a}$ & $26.28 \mathrm{a}$ & $3.79 \mathrm{a}$ & $5.76 \mathrm{a}$ & $32.13 \mathrm{~b}$ \\
\hline LSD 5\% & 0.69 & 0.89 & 0.71 & 0.82 & 2.19 & 0.51 & 0.57 & 2.94 \\
\hline E0 & $8.47 \mathrm{c}$ & $11.25 \mathrm{~d}$ & $3.00 \mathrm{c}$ & $9.17 \mathrm{c}$ & $15.21 \mathrm{c}$ & $2.63 \mathrm{~b}$ & $2.80 \mathrm{c}$ & $37.84 \mathrm{a}$ \\
\hline E1 & $9.53 \mathrm{~b}$ & $14.25 \mathrm{c}$ & $9.75 \mathrm{~b}$ & $10.23 \mathrm{~b}$ & $19.28 \mathrm{~b}$ & $3.29 \mathrm{a}$ & $3.39 \mathrm{c}$ & $34.93 \mathrm{a}$ \\
\hline E2 & $10.58 \mathrm{a}$ & $16.50 \mathrm{~b}$ & $4.25 \mathrm{ab}$ & $11.20 \mathrm{a}$ & $25.03 \mathrm{a}$ & $3.58 \mathrm{a}$ & $4.46 \mathrm{~b}$ & $31.47 \mathrm{~b}$ \\
\hline E3 & $11.17 \mathrm{a}$ & $17.42 \mathrm{a}$ & $4.58 \mathrm{a}$ & $11.90 \mathrm{a}$ & $26.28 \mathrm{a}$ & $3.76 \mathrm{a}$ & $5.58 \mathrm{a}$ & $31.67 \mathrm{~b}$ \\
\hline LSD 5\% & 0.69 & 0.89 & 0.71 & 0.82 & 2.19 & 0.51 & 0.44 & 2.94 \\
\hline
\end{tabular}

Note: The average value followed by the same lowercase letter in the same column means that it is not significantly different at Duncan 5\%

Table 3

Table of mean fresh weight per clump due to the interaction effect between biochar and ecoenzyme concentration

\begin{tabular}{ccccc}
\hline Treatment & E0 & E1 & E2 & E3 \\
\hline B0 & 11.631 & $14.63 \mathrm{fgh}$ & $17.00 \mathrm{fgh}$ & $17.63 \mathrm{fg}$ \\
B1 & $13.80 \mathrm{l}$ & $19.67 \mathrm{def}$ & $28.20 \mathrm{ab}$ & $30.63 \mathrm{a}$ \\
B2 & $16.13 \mathrm{fgh}$ & $18.50 \mathrm{efg}$ & $23.27 \mathrm{cde}$ & $27.33 \mathrm{abc}$ \\
B3 & $19.27 \mathrm{ef}$ & $24.33 \mathrm{bcd}$ & $31.67 \mathrm{a}$ & $29.50 \mathrm{a}$ \\
\hline
\end{tabular}

Note: The average value followed by the same lowercase letter in the same column means that it is not significantly different at Duncan 5\%.

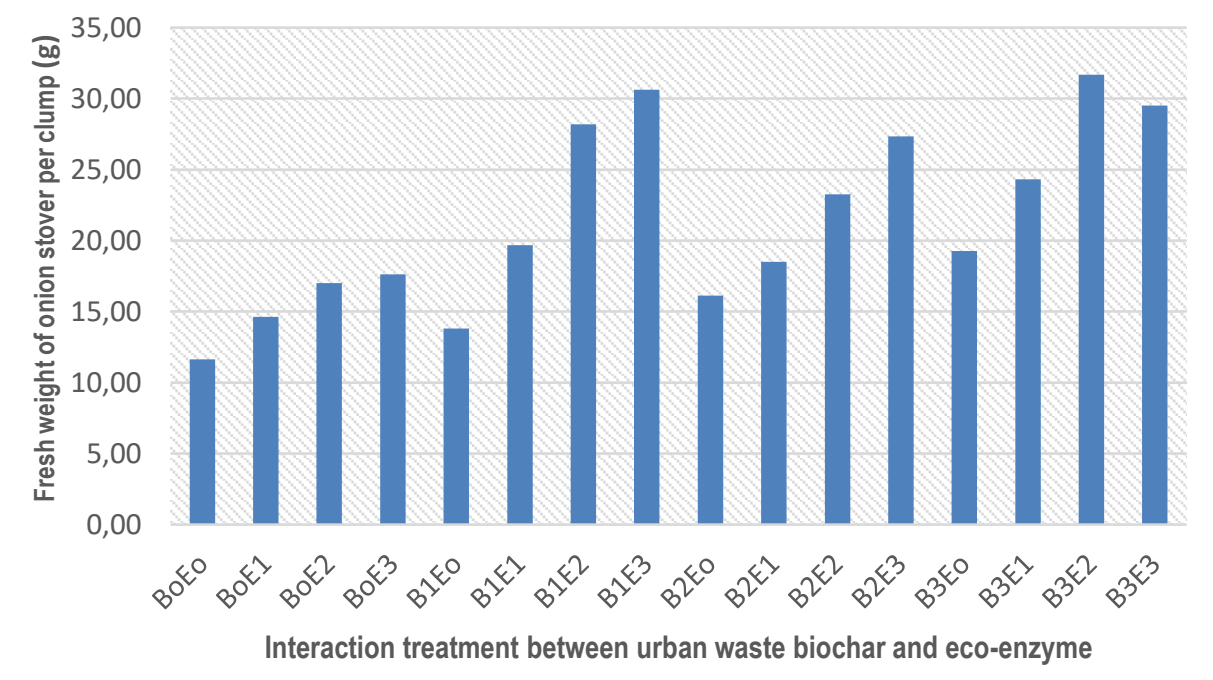

Figure 1. The interaction effect of urban waste biochar dose and eco-enzyme concentration on the fresh weight of shallot stover per clump 
Table 4

The correlation coefficient between variables $(\mathrm{r})$ on the interaction of biochar dose treatment and eco-enzyme

\begin{tabular}{ccccccccc}
\hline & 1 & 2 & 3 & 4 & 5 & 6 & 7 & 8 \\
\hline 1 & 1 & & & & & & & \\
2 & $0.940^{* *}$ & 1 & & & & & & \\
3 & $0.636^{* *}$ & $0.845^{* *}$ & 1 & & & & & \\
4 & $0.891^{* *}$ & $0.965^{* *}$ & $0.840^{* *}$ & 1 & & & \\
5 & $0.812^{* *}$ & $0.909^{* *}$ & $0.875^{* *}$ & $0.899^{* *}$ & 1 & & \\
6 & $-0.360 \mathrm{~ns}$ & $-0.079 \mathrm{~ns}$ & $0.388^{* *}$ & $-0.059 \mathrm{~ns}$ & $0.113 \mathrm{~ns}$ & 1 & \\
7 & $0.066 \mathrm{~ns}$ & $0.308 \mathrm{~ns}$ & $0.610^{* *}$ & $0.340 \mathrm{~ns}$ & $0.374 \mathrm{~ns}$ & $0.782 \mathrm{~ns}$ & 1 & \\
8 & $-0.268 \mathrm{~ns}$ & $-0.342 \mathrm{~ns}$ & $-0.370 \mathrm{~ns}$ & $-0.363 \mathrm{~ns}$ & $-0.365 \mathrm{~ns}$ & $-0.267 \mathrm{~ns}$ & $-0.161 \mathrm{~ns}$ & 1 \\
\hline $\mathrm{r}(0.05 ; 25 ; 1)=0.3809$ & & \multicolumn{5}{c}{$\mathrm{r}(0.01 ; 25 ; 1)=0.4869$} & &
\end{tabular}

Note:

1. Maximum plant height $(\mathrm{cm})$

2. Maximum number of leaves (strands)

3. Number of tubers (tubers)

4. Fresh tuber weight per clump $(\mathrm{g})$

5. Fresh weight of stover per clump $(\mathrm{g})$

6. Oven dry tubers weight per clump $(\mathrm{g})$

7. Oven dry weight per clump $(\mathrm{g})$

8. Harvest index $(\%)$

$*$ = Significantly influential $(\mathrm{p}<0.05)$

$* *=$ Very significant effect $(\mathrm{p}<0.01)$

ns $=$ Not significant

Table 5

The correlation coefficient between variables (r) due to the effect of biochar from urban waste

\begin{tabular}{|c|c|c|c|c|c|c|c|c|}
\hline & 1 & 2 & 3 & 4 & 5 & 6 & 7 & 8 \\
\hline 1 & 1 & & & & & & & \\
\hline 2 & $0.979 * *$ & 1 & & & & & & \\
\hline 3 & $0.325 \mathrm{~ns}$ & $0.312 \mathrm{~ns}$ & 1 & & & & & \\
\hline 4 & $0.957 * *$ & $0.993 * *$ & $0.249 \mathrm{~ns}$ & 1 & & & & \\
\hline 5 & $0.947 * *$ & $0.966 * *$ & $0.546^{*}$ & $0.944 * *$ & 1 & & & \\
\hline 6 & $-0.908 * *$ & $-0.809 * *$ & $-0.294 \mathrm{~ns}$ & $-0.751 * *$ & $-0.780 * *$ & 1 & & \\
\hline 7 & $0.320 \mathrm{~ns}$ & $0.398 \mathrm{~ns}$ & $-0.163 n s$ & $0.489 \mathrm{~ns}$ & $0.313 \mathrm{~ns}$ & $-0.020 \mathrm{~ns}$ & 1 & \\
\hline 8 & $0.964 * *$ & $0.902 * *$ & $0.207 \mathrm{~ns}$ & $0.864 * *$ & $0.843 * *$ & $-0.974 * *$ & $0.153 \mathrm{~ns}$ & 1 \\
\hline
\end{tabular}

Note:

1. Maximum plant height $(\mathrm{cm})$

2. Maximum number of leaves (strands)

3. Number of tubers (tubers)

4. Fresh tuber weight per clump (g)

5. Fresh weight of stover per clump (g)

6. Oven dry tubers weight per clump (g)

7. Oven dry weight per clump (g)

8. Harvest index (\%)

* = Significantly influential $(\mathrm{P}<0.05)$

$* *=$ Very significant effect $(\mathrm{P}<0.01)$

$\mathrm{ns}=$ Not significant 
Table 6

The correlation coefficient between variables (r) is due to the effect of eco-enzyme concentration.

\begin{tabular}{ccccccccc}
\hline & 1 & 2 & 3 & 4 & 5 & 6 & 7 & 8 \\
\hline 1 & 1 & & & & & & & \\
2 & $0.990^{* *}$ & 1 & & & & & \\
3 & $0.747^{*}$ & $0.832^{* *}$ & 1 & & & & \\
4 & $0.997^{* *}$ & $0.997^{* *}$ & $0.798^{* *}$ & 1 & & & \\
5 & $0.949^{* *}$ & $0.980^{* *}$ & $0.902^{* *}$ & $0.969^{* *}$ & 1 & & \\
6 & $-0.829^{* *}$ & $-0.742^{* *}$ & $-0.248 \mathrm{~ns}$ & $-0.782^{* *}$ & $-0.624^{*}$ & 1 & & \\
7 & $-0.587^{*}$ & $-0.476 \mathrm{~ns}$ & $0.082 \mathrm{~ns}$ & $-0.519^{*}$ & $-0.312 \mathrm{~ns}$ & $0.922^{* *}$ & 1 & \\
8 & $0.891^{* *}$ & $0.819^{* *}$ & $0.367 \mathrm{~ns}$ & $0.852^{* *}$ & $0.708^{* *}$ & $-0.990^{* *}$ & $-0.879^{* *}$ & 1 \\
\hline $\mathrm{r}(0.05 ; 10 ; 1=0.4973$ & & & & & $\mathrm{r}(0.01 ; 10 ; 1)=0.6581$ &
\end{tabular}

Note:

1. Maximum plant height $(\mathrm{cm})$

2. Maximum number of leaves (strands)

3. Number of tubers (tubers)

4. Fresh tuber weight per clump $(\mathrm{g})$

5. Fresh weight of stover per clump $(\mathrm{g})$

6. Oven dry tubers weight per clump $(\mathrm{g})$

7. Oven dry weight per clump $(\mathrm{g})$

8. Harvest index (\%)

$*$ = Significantly influential $(\mathrm{p}<0.05)$

$* *=$ Very significant effect $(\mathrm{p}<0.01)$

$\mathrm{ns}=$ Not significant

The interaction between the treatment dose of municipal waste biochar (B) on the fresh weight of the husk per clump and a very significant effect $(\mathrm{P}<0.01)$ on the oven-dry weight of the shell per clump, but no effect. significantly $(\mathrm{P} \geq 0.05)$ to other variables biochar treatment $(\mathrm{B})$ caused soil porosity to increase so that root absorption of nutrients was better and faster through leaf and stem stomata and penetrated directly into tissue cells (Table 1). The results of this study, which showed that the highest fresh weight was obtained from the interaction between biochar of municipal waste 15 tons ha ${ }^{-1}$ with a concentration of eco-enzyme $22.5 \mathrm{ml}^{-1}$ (B3E2), which was $29.50 \mathrm{~g}$, an increase of $172.12 \%$ compared to interactions without biochar and without eco-enzyme (B0E0) which is 11.63 $\mathrm{g}$ (Table 3). The high fresh weight per clump at the dose of biochar and the concentration of ecoenzyme (BxE) was supported by a significant correlation in the variables studied, such as maximum plant height $\left(\mathrm{r}=0.812^{* *}\right)$, number of leaves per clump $\left(\mathrm{r}=0.909^{* *}\right)$, number of tubers per clump $(\mathrm{r}$ $\left.=0.875^{* *}\right)$, and fresh weight of tuber per clump $\left(\mathrm{r}=0.889^{* *}\right)$ (Table 4 and Figure 1).

The results of this study showed that the highest fresh weight of tubers was obtained in the treatment dose of biochar 15 tons ha ${ }^{-1}$ (B3), which was $12.17 \mathrm{~g}$, an increase of $39.40 \%$ compared to the treatment without biochar in municipal waste (B0), which was 8.73. g. The high fresh weight of tubers per clump at the dose of biochar (B) was supported by a significant correlation in the variables studied, such as maximum plant height $\left(0.957^{* *}\right)$, number of leaves per clump $\left(\mathrm{r}=0.993^{* *}\right)$, fresh weight per clump $(\mathrm{r}=0.994 * *)$, and harvest index $(\mathrm{r}=0.864 * *)$ (Table 5).

The giving of eco-enzyme (E) as a soil enhancer, facilitates plant growth and provides good crop yields. The results of this study showed that the highest fresh weight of tubers was at the concentration of eco-enzyme $22.5 \mathrm{ml} \mathrm{l}^{-1}$ (E3), which was $11.90 \mathrm{~g}$, which increased by $29.77 \%$ compared to those who did not give eco-enzyme treatment (E0) which is $9.17 \mathrm{~g}$. The high fresh weight of tubers was influenced by eco-enzyme (E) which was supported by a significant correlation in the variables studied such as maximum plant height $\left(\mathrm{r}=0.997^{* *}\right)$, number of leaves $\left(\mathrm{r}=0.997^{* *}\right)$, number of tuber per clump $\left(\mathrm{r}=0.798^{* *}\right)$, bean fresh weight $\left(\mathrm{r}=0.969^{* *}\right)$, and harvest index $(\mathrm{r}=$ $0.852 * *$ ) (Table 6). 
The results of this study showed that there was an effect of biochar and eco-enzyme treatment on the fresh weight of tubers per clump due to an increase in the main cations N, P, K in the soil. Sourcebased waste that is used as pellets for biomass gasification power plants, in addition to producing electrical energy, the waste product is also obtained in the form of charcoal waste (biochar) which is useful for improving agricultural soil. The results of this study indicate that the application of 15 tons per ha of biochar from biomass gasification power plant residues from urban waste pellets can increase the yield of shallots. Biochar is a soil enhancer that can hold nutrients and water in the soil. This is supported by the results of research [24], which states that the application of biochar can increase the cation exchange capacity in the soil, $\mathrm{Ca}, \mathrm{Mg}, \mathrm{P}$, and $\mathrm{K}$, increasing crop yields (20-120\%), improving the quality of crop products. If the availability of nutrients for plants is higher, maximum results will be obtained because of the addition of nutrients directly from biochar, and changes in microbial dynamics in the soil. Long-term benefits for nutrient availability are associated with higher organic carbon stabilization along with slower nutrient release compared to commonly used organic matter. Biochar is a soil enhancer that can hold nutrients and water in the soil. Nutrient and water retention affect nutrient growth for plants, due to the nature of biochar which can improve soil aeration due to improved soil porosity, decreased soil compaction, and increased soil CEC. This statement is supported by [25, 26, 27], that the application of biochar can improve soil fertility and increase plant growth and yield. Biochar has a significant effect on soil microbial-mediated nutrient transformation [28].

The provision of eco-enzymes affects the yield of fresh weight of tubers per clump due to soil fertility to facilitate plant growth, stimulate plant hormones, improve fruit and vegetable quality, and increase crop yields. This is supported by research [29] which shows that eco-enzyme organic waste is expressed in the form of kitchen waste into a more useful product and can be used to increase agricultural productivity and research [30] states that eco-enzymes can fertilize plants and replace chemical fertilizers. so that it can reduce agricultural costs, dissolve quickly in the soil, is quickly absorbed by plant roots, is more evenly distributed, and does not accumulate in the concentration of fertilizers in certain places and most importantly eco-enzymes can increase productivity in agriculture.

\section{Conclusion}

Biochar treatment from urban waste and the concentration of interacting eco-enzymes had a very significant effect on dry weight per clump and significantly on fresh weight of stover per clump, but other variables had no significant effect. The application of biochar and eco-enzymes had a very significant effect on all observed variables. The highest fresh weight of tubers per clump was obtained in the 15 ton $\mathrm{ha}^{-1}$ biochar treatment, which increased $39.40 \%$ compared to without biochar. The highest fresh weight of tubers per clump was found at the eco-enzyme concentration of $22.5 \mathrm{ml}$ $1^{-1}$ which increased $39.77 \%$ compared to without the eco-enzyme.

\section{References}

[1] Irwan (2020). Bawang merah dan pestisida. http://www. Waspada.co.id/serba artikel serbi/kesehatan php pasal-id=7849811. Diakses 24 Januari.

[2] Direktorat Jenderal Hortikultura (2012). Pedoman Umum Program Peningkatan Produksi, Produktivitas dan Kualitas Produk Hortikultura Berkelanjutan untuk Tahun Anggaran 2012. Direktorat Jenderal Hortikultura. Departemen Pertanian.

[3] Dinas Pertanian Provinsi Bali, (2019). https://bali.bps.go.id/indicator/55/332/1/hasil-bawangmerah-provinsi-bali-menurut-kabupaten-kota.html. 
[4] Parnata, A.S. (2010). Meningkatkan Hasil Panen dengan Pupuk Organik. Agromedia Pustaka. Jakarta.

[5] Rahayu, E, dan Berlian, N, (2007). Bawang Merah. Penebar Swadaya. Jakarta.

[6] International Biochar Initiative, (2012). What is Biochar?.. www.biochar-international.org

[7] Adhi, R. K. (2013). Biochar sang pembenah tanah. Balai Besar Pelatihan Binaung.

[8] Endriani, L. A. (2013). Pemanfaatan Kulit Jengkol (Pithecellobium jiringa) Sebagai Bioherbisida Gulma dan Biolarvasida Aedes aegepty. Universitas Negeri Medan. Medan.

[9] Stewart, C. E., Zheng, J., Botte, J., \& Cotrufo, M. F. (2013). Co-generated fast pyrolysis biochar mitigates greenhouse gas emissions and increases carbon sequestration in temperate soils. Gcb Bioenergy, 5(2), 153-164.

[10] Thies, J. E., \& Rillig, M. C. (2012). Characteristics of biochar: biological properties. In Biochar for environmental management (pp. 117-138). Routledge.

[11] Sukartono, S., \& Utomo, W. H. (2012). Peranan biochar sebagai pembenah tanah pada pertanaman jagung di tanah lempung berpasir (sandy loam) semiarid tropis Lombok Utara. Buana Sains, 12(1), 91-98.

[12] Situmeang, Y.P. dan Sudewa, K.A. (2013). Respon Pertumbuhan Vegetatif Tanaman Jagung Pulut pada Aplikasi Biochar Limbah Bambu. Prosiding Seminar Nasional. Fakultas Pertanian Universitas Warmadewa. Denpasar.

[13] Situmeang, Y. P., Adnyana, I. M., Subadiyasa, I. N. N., \& Merit, I. N. (2015). Effect of Dose Biochar Bamboo, Compost, and Phonska on Growth of Maize (Zea mays L.) in Dryland. International Journal on Advanced Science, Engineering and Information Technology, 5(6), 433-439.

[14] Yurnanelli, (2020). "Pengaruh Biochar Cangkang Kelapa Sawit dan Pupuk Kandang Ayam Terhadap Distribusi Pori Tanah Ultisol dan Hasil Kedelai." Jurnal Penelitian Pertanian.

[15] Dapa, D. S., Situmeang, Y. P., \& Sudewa, K. A. (2019). The Use of Biochar From Cow Feces and Bioboost in The Red Chili Plant (Capsicum annum L). SEAS (Sustainable Environment Agricultural Science), 3(2), 118-123.

[16] Situmeang Y P, Sudita I D Y, and Suarta M (2019). Manure Utilization from Cows, Goats, and Chickens as Compost, Biochar, and Poschar in Increasing the Red Chili Yield International Journal on Advanced Science, Engineering and Information Technology, 9(6), 2088-2095.

[17] Mahendra, K. A., Situmeang, Y. P., \& Suarta, M. (2020). Effect of Biochar and Compost from Chicken, Goat, and Cow Manure on Cultivation of Red Chili (Capsicum annuum L). SEAS (Sustainable Environment Agricultural Science), 4(2), 95-101.

[18] Damayanti, S., Situmeang, Y. P., \& Wirajaya, A. A. N. M. (2020). Biochar and Compost Application of Livestock on The Growth and Results of Red Chili Plants. SEAS (Sustainable Environment Agricultural Science), 4(2), 88-94.

[19] Muliarta, I. N., \& Darmawan, I. K. (2021). Processing Household Organic Waste Into EcoEnzyme As An Effort To Realize Zero Waste. Agriwar Journal, 1(1), 6-11.

[20] Rahayu, M. R., Muliarta, I. N., and Situmeang, Y. P. (2021). Acceleration of Production Natural Disinfectants from the Combination of Eco-Enzyme Domestic Organic Waste and Frangipani Flowers (Plumeria alba). SEAS (Sustainable Environment Agricultural Science), 5(1), 15-21.

[21] Retno, I. (2010). Hindari banjir sampah (2012). https://nokiagreenmbassador.com.

[22] Eco-enzyme Nusantara, (2021). Https://www.kompas.id/baca/ilmu-pengetahuan

[23] Dinas Lingkungan Hidup Kota Cimahi (2018). Eco Enzim. Info Public. https://dlh.cimahikota.go.id/article/detail?id=21.

[24] Gani, A. (2010). Multiguna arang-hayati biochar. Sinar Tani Edisi, 2010, 13-19.

[25] Situmeang, Y. P., Adnyana, I. M., Subadiyasa, I. N. N., \& Merit, I. N. (2018). Effectiveness of Bamboo Biochar combined with compost and NPK fertilizer to improved soil quality and corn yield. International Journal on Advanced Science, Engineering and Information Technology, 8(5), 2241-2248.

[26] Situmeang, Y.P. (2018). Soil quality in corn cultivation using bamboo biochar, compost, and phonska. In MATEC Web of Conferences (Vol. 197, p. 13001). EDP Sciences. 
[27] Putra, I. G. L. A. A. A., Situmeang, Y. P., Yuliartini, M. S., \& Udayana, I. G. B. (2019). Application of biochar and compost to changes in physical and chemical properties of soil and corn yield on dry land. In Journal of Physics: Conference Series (Vol. 1402, No. 5, p. 055029). IOP Publishing.

[28] Bailey, V. L., Fansler, S. J., Smith, J. L., \& Bolton Jr, H. (2011). Reconciling apparent variability in effects of biochar amendment on soil enzyme activities by assay optimization. Soil biology and biochemistry, 43(2), 296-301.

[29] Tang, F. E., \& Tong, C. W. (2011). A study of the garbage enzyme's effects in domestic wastewater. World Academy of Science, Engineering and Technology, 60, 1143-1148.

[30] Serikat Tani Indonesia. (2012). Pupuk buah cair untuk meningkatkan produksi. https://spi.or.id/pupuk buah-cair-to-ingkatkan-hasil/. Diakses pada 10 September 2019. 